\title{
HUBUNGAN STRATEGI MEMBACA DENGAN KEMAMPUAN MEMAHAMITEKS BACAAN BAHASA INDONESIA MAHASISWA PRODI PENDIDIKAN BAHASA DAN SASTRA INDONESIA FKIP UMSB PADANGPANJANG
}

\author{
Mimi Sri Irfadila \\ Dosen Prodi Pendidikan Bahasa dan Sastra Indonesia, FKIP UMSB \\ mimifadila85@gmail.com \\ Submitted :10-05-2016, Reviewed:15-10-2016, Accepted:31-10-2016 \\ http://dx.doi.org/10.22202/jg.2015.v1i1.1157
}

\begin{abstract}
This study aims to describe the correlation between the use of strategies in reading comprehension by students against tesk reading comprehension in the form of a report. The data collection is done by using a written test, which tests reading comprehension and reading strategies questionnaire. The method used in this research is descriptive method. While this type of research is combined (mixing) between the types of quantitative and qualitative research. These results indicate that there is a relationship between reading strategies with the ability to understand the reading text on a student Prodi Indonesian Indonesian language and literature education. The results showed an association between the use of strategies with reading comprehension. If a high reading comprehension strategies, reading comprehension is also high, otherwise if low reading comprehension strategies reading comprehension will also be low.

Keywords: strateggi reading, reading comprehension.
\end{abstract}

\begin{abstract}
Abstrak
Penelitian ini bertujuan menggambarkan korelasi antara pemakaian strategi di dalam membaca pemahaman dengan pemahaman mahasiswa terhadap tesk bacaan dalam bentuk membuat laporan. Pengumpulan data dilakukan dengan menggunakan tes tertulis, yaitu tes kemampuan membaca pemahaman dan angket strategi membaca. Metode yang digunakan dalam penelitian ini adalah metode deskriptif. Sedangkan jenis penelitian ini adalah penelitian gabungan (mixing) antara jenis penelitian kuantitatif dan kualitatif. Hasil penelitian ini menunjukan bahwa terdapat hubungan antara strategi membaca dengan kemampuan memahami teks bacaan bahasa Indonesia pada mahasiswa prodi pendidikan bahasa dan sastra Indonesia. Hasil penelitian menunjukkan adanya hubungan antara penggunaan strategi dengan kemampuan membaca pemahaman. Apabila strategi membaca pemahaman tinggi, kemampuan membaca pemahaman juga
\end{abstract}


tinggi, sebaliknya apabila strategi membaca pemahaman rendah kemampuan membaca pemahaman juga akan rendah.

Kata kunci: strateggi membaca, membaca pemahaman.

\section{PENDAHULUAN}

Perkembangan Bahasa Indonesia tumbuh dan berkembang secara terus menerus sesuai dengan perkembangan manusia serta bersamaan dengan berkembangnya kebudayaan di Indonesia. Perkembangan tersebut tidak terlepas juga peran media massa, cetak maupun elektronik sebagai salah satu media penyebar informasi.

Penyebaran informasi melalui media cetak dewasa ini makin mendapat perhatian, baik dari kalangan masyarakat intelektual maupun dari kalangan masyarakat biasa. Kemampuan memperoleh informasi melalui media cetak makin penting dalam masyarakat, sebab teknologi-teknologi canggih pada umumnya berkaitan dengan media cetak.

Bila dibandingkan dengan media komunikasi lainnya, media cetak mempunyai kelebihan khusus. Di antaranya, media cetak dapat diperoleh dan dibawa dengan cara mudah. Informasi yang terkandung di dalamnya dapat dinikmati berdasarkan keinginan pembaca serta dapat dinikmati kanpan saja. Media cetak ini pun bermacam-macam seperti koran, majalah, dan tabloid. Teks bacaan yang ada di dlam media cetak terbut dapat dimanfaatkan sebagai sumber belajar. Mahasiswa sebagai subjek dalam proses kegiatan belajar mengajar dituntut lebih banyak membaca, sebab ilmu pengetahuan umumnya bersumber dari teks bacaan. Melalui teks bacaan atau buku mahasiswa dapat memperoleh informasi dan ide-ide yang terkandung di dalamnya.

Agar tercapai keberhasilan dalam memperoleh informasi dan memahami isi dari teks bacaan, dibutuhkan strategi atau teknik-teknik membacayang tepat. Strategi merupakan prosedur-prosedur yang dipakai dalam belajar, berfikir, dan lain-lain yang bertindak sebagai suatu cara untuk mencapai tujuan. Sedangkan tujuan pemakaian strategi adalah untuk mempengaruhi keadaan motivasi atau efektif bagi pembelajar dan menyeleksi, memperoleh, mengorganisasi, atau mengintegrasikan pengetahuan baru. Oleh sebab, keterampilan membaca pemahaman membutuhkan strategi yang berintegrasi dengan materi yang dipelajari secara mental atau secara fisik adalah strategi kognitif, yang berhubungan dengan pengetahuan, kemampuan berfikir, dan pemahaman.

Tujuan dari pengajaran membaca pada dasarnya adalah memberi bekal pengetahuan dan kemampuan untuk menguasai teknik-teknik membaca setra menangkap isi bacaan dengan baik, DEPDIKBUD (2000). Pembelajaran 
membaca lanjutan (pemahaman) bertujuan agar pelajar mampu mengambil manfaat dan pesan yang disampaikan penulis yang terdapat dalam bacaan. Dengan kata lain, perlu keterampilan untuk memahami isi, menyerap pikiran dan perasaan orang lain melalui tulisan. Maka keterampilan membaca lanjutan atau membaca pemahaman akan terlihat dari hasil belajar serta produk yang dihasilakan dari keterampilan tersebut, di antaranya mampu membuat laporan bacaan.

Keberhasilan seseorang dalam mencapai pemahaman yang baik terhadap suatu bacaan ditentukan oleh usaha dalam memahami bacaan. Pemanfaatan pengetahuan dan keterampilan yang memadai memberikan kemudahan dalam memperoleh informasi bacaan serta membuat laporan bacaan. Jadi, segala informasi dapat dipahami dengan menggunakan keterampilan membaca pemahaman yang baik diperkirakan akan menghasilkan laporan bacaan yang berkualitas pula.

Oleh sebab itu, artikel ini akan menyajikan bagaimana hubungan strategi membaca pemahaman dengan kemampuan memahami teks bacaan dalam bentuk laporan bacaan pada mahasiswa prodi bahasa dan sastra Indonesia FKIP UMSB.

Membaca adalah suatu proses yang kompleks dan rumit. Kompleks artinya melibatkan faktor internal dan faktor eksternal pembaca. Faktor internal adalah faktor yang bersangkutan dengan bagian dalam diri pembaca, yang terdiri dari intelegensi (IQ), minat, sikap, bakat, motivasi, tujuan membaca, dan sebagainya. Faktor eksternal adalah faktor yang bersangkutan dengan hal-hal luar atau datang dari luar, contohnya bisa dalam bentuk sarana membaca teks bacaan, lingkungan, atau faktor latar belakang sosial ekonomi, kebiasaan dan tradisi membaca. Sedangkan rumit artinya bertautan atau berhubungan antara kedua faktor tersebut yang membentuk semacam koordinasi yang rumit untuk menunjang pemahaman terhadap bacaan. Jadi, dapat disimpulkan bahwa pada saat membaca, pembaca dipengaruhi oleh beberapa faktor yang saling terkait. Dengan banyak membaca siswa akan kaya dengan kata. Semakin banyak membaca, kekayaan yang ada dalam diri pun akan luar biasa beraneka ragamnya (Nurhadi, 2003). Membaca merupakan suatu keterampilan (Ermanto, 2008:1). Suatu keterampilan yang melibatkan berbagai faktor dan kesiapan si pembaca dalam memahami isi dari teks bacaan tersebut. Di samping itu, membaca juga membutuhkan keterampilan di dalam menangkap informasi secara tersurat dan tersirat dari sebuh teks bacaan.

Membaca juga bukan sekedar melafalkan hufur demi huruf dengan baik, tetapi juga melibatkan aktivitas mental yang terarah agar dapat 
menangkap makna yang terkandung di dalam bacaan tersebut. Sejalan dengan itu, Marhiyanto (2007) mengatakan bahwa embaca adalah suatu keterampilan berbahasa dalam bentuk kegiatan melihat serta memahami isi tulisan, baik dengan cara diujarkan maupun hanya dalam hati.

Menurut Agustina (2008) secara garis besar membaca berlangsung dalam empat proses yaitu: (1) pengamatan dan pemahaman terhadap lambang-lambang bahasa, (2) pemahaman atau penangkapan makna yang ada dibalik lambang tersebut, baik makna pokok maupun makna tambahan, (3) bereaksi secara interpretatif terhadap hasil bacaan baik secara positif maupun negatif, dan (4) mengintegrasikan atau mengidentifikasikan gagasan-gagasan dengan pengalaman dan pengetahuan yang ada, pada akhirnya memberi pengaruh terhadap individu yang bersangkutan terlihat dalam wujud pengayaan pengalaman, perubahan terhadap sikap kearah yang baik, perubahan cara berfikir kearah positif, dan pembinaan daya nalar.

Dengan kata lin, membaca adalah suatu kegiatan atau keterampilan kompleks yang dilakukan seseorang untuk memahami isi suatu bacaan, memperoleh pesan atau memperoleh informasi dari media yang dibaca.

Agustina (2008) juga mengemukakan bahwa membaca pemahaman adalah membaca yang dilakukan tanpa mengeluarkan bunyi atau suara. Membaca jenis ini tidak dituntut pembacanya untuk membunyikan atau mengoralkan bacaannya, tetapi hanya menggunakan mata untuk melihat dan hati serta pikiran untuk memahaminya.

Membaca pemahaman merupakan membaca untuk mendapatkan dan memahami informasi agar dapat menguraikan dan menciptakan kembali. Membaca jenis ini tidak hanya terbatas pada tulisan-tulisan ilmiah saja. Seorang bisa saja melakukan membaca pemahaman terhadap karya sastra seperti puisi, prosa, dan drama (naskah drama), serta tulisan-tulisan semi ilmiah. Dengan demikian, pembaca akan mengenal norma-norma dalam kesastraan, dan mengenal pola-pola fiksi dan nonfiksi, dan serta mendapatkan informasi atau gagasan nantinya yang dapat diceritakan secara lisan atau tulisan.

Keterampilan membaca pemahaman mengharuskan seseorang mampu menangkap pokok-pokok pikiran yang lebih tajam sehingga setelah selesai membaca, ia betul-betul memahami makna dan tujuan bacaan (Marhiyanto, 2007). Jadi, keterampilan membaca pemahaman adalah suatu cara membaca agar mudah memahami suatu bahan bacaan. Dengan cara ini akan mempermudah dalam menentukan pokok-pokok pikiran setiap alinea, yang sendirinya turut mempermudah dalam memahami materi bacaan secara 
keseluruhan. Keterampilan yang bersifat pemahaman, tidak saja mengenal bentuk-bentuk visual tetapi lebih mencapai terhadap tulisan, baik pemahaman sederhana apa yang tersurat, maupun pemahaman penafsiran terhadap suatu tulisan, sehingga tercapai kecepatan membaca.

Secara garis besar membaca dapat dikelompokkan dalam dua golongan, yaitu membaca intensif dan membaca ekstensif (Agustina: 2008). Sementara itu, Broughton cs (dalam Tarigan, 1979) menyatakan bahwa membaca ekstensif meliputi tiga bagian yaitu: a) membaca survei, b) membaca sekilas, dan c) membaca dangkal.

Membaca intensif merupakan studi seksama, telaah teliti, dan penanganan terperinci yang dilaksanakan di dalam kelas terhadap suatu tugas yang pendek kira-kira dua sampai empat halaman setiap hari (Brook dalam Tarigan, 1979). Membaca intensif dapat dikelompokkan menjadi: a) membaca telaah isi dan b) membaca telaah bahasa.

Linda (2009:11) menyatakan bahwa tujuan membaca pemahaman adalah untuk mencari informasi diantaranya: (1) kognitif dan intelektual, yakni digunakan seseorang untuk menambah keilmiahan sendiri, (2) referensial dan faktual, yakni digunakan seseorang untuk mengetahui fakta-fakta yang nyata didunia dan (3) afektif dan emosional, yakni yang digunakan untuk mencari kenikmatan dalam membaca. Menurut Agustina
(2008:15), membaca pemahaman bertujuan untuk menangkap isi atau makna dari gagasan yang terdapat dalam bacaan, yang berbentuk pengertian-pengertian dan penafsiran-penafsiran yang tidak menyimpang dari gagasan atau ide yang disampaikan dalam bacaan.

Strategi atau teknik merupakan prosedur-prosedur yang digunakan untuk mencapai tujuan yang telah ditetapkan (Tarigan, 1991). Tujuan dari pemakaian strategi adalah untuk mempengaruhi keadaan motivasi atau efektif bagi pembelajar dan menyeleksi, memperoleh, mengorganisasi, atau mengintegrasikan pengetahuan baru). Strategi-strategi pembelajaran bahasa tersebut di antaranya a) strategi metakognitif, b) strategi kognitif, dan c) strategi sosial atau afektif

Sementara itu, strategi-strategi yang dapat diajarkan untuk membaca pemahaman adalah: 1) Rehearsal atau pengulangan nama-nama butir atau objek yang telah dibaca. 2) Organization atau pengelompokkan atau pengklasifkasian kata-kata, istilah-istilah, atau konsep yang telah dibaca berdasarkan ciri-ciri semantik dan sintaktik. 3) Inferencing atau pemakaian informasi dalam teks untuk menduga makna butir-butir linguistik baru, meramalkan hasil, atau melengkapi bagian-bagian yang hilang. 4) Summarizing atau pensintesisan secara segera apa-apa yang telah dibaca untuk 
meyakinkan bahwa informasi telah dipahami. 5) Deduction atau penerapan kaidah-kaidah untuk memahami bahasa bacaan. 6) Imagery atau penggunaan imaji-imaji visual untuk memahami atau mengingat informasi verbal baru dari bacaan. 7) Transfer atau penggunaan informasi linguistik yang telah diketahui untuk memberi kemudahan bagi tugas pembaca baru. 8) Elaboration atau perangkaian ide-ide baru dengan informasi yang telah diketahui sebelumnya.

Agustina (2008), menjelaskan bahwa ada enam cara teknik pembelajaran membaca pemahaman, yaitu teknik menjawab pertanyaan, teknik meringkas bacaan, teknik mencari ide pokok, teknik melengkapi paragraf, teknik isian rumpang (group cloze), teknik menata bacaan (group sequensing).

\section{METODE PENELITIAN}

Penelitian ini menggunakan penelitian gabungan (mixing) dengan metode deskriptif Sugiyono (2009:26). Menurut Nazir (2005:54) metode deskriptif adalah suatu metode dalam meneliti suatu kelompok manusia, suatu objek, suatu kondisi, suatu sistem pemikiran, ataupun suatu kelas peristiwa pada masa sekarang. Alasan peneliti menggunakan metode deskriptif didasari oleh tujuan penelitian ini sendiri. Tujuan dari penelitian ini adalah untuk membuat deskripsi, gambaran, atau lukisan secara sistematis, faktual dan akurat mengenai fakta-fakta yang diselidiki.

Populasi dalam penelitian ini adalah mahasiswa prodi pendidikan bahasa dan sastra Indonesia semester V. Jumlah mahasiswa semester V semester I yang terdaftar pada tahun pelajaran 2014/2015 sebanyak 28 orang. Sampel dalam penelitian ini dipiliha dengan teknik total sampling berjumlah 28 orang.

$\begin{array}{lrr} & \text { data dianalisis dengan mengubah } \\ \text { skor menjadi nilai, kemudian } & \\ \text { menentukan nilai rata-rata yang } \\ \text { dikelompokkan dalam skala } 10 .\end{array}$ Selanjutnya ditentukan standar deviasi, mean untuk selanjutkanya mengkorelasi kedua variabel dengan menggunakan rumus korelasi produk moment.

\section{Pembahasan}

\section{Strategi Membaca Pemahaman siswa Kelas V SDN 04 Paninggahan}

Data strategi membaca pemahaman diperoleh melalui angket, dalam angket tersebut mahasiswa diminta untuk memberikan pernyataan mengenai tes membaca pemahaman yang telah dikerjakan sebelumnya. Setelah data terkumpul, data tersebut kemudian dinilai berdasarkan jawaban yang dipilih siswa, yaitu jawaban A dengan bobot 3, jawaban B dengan bobot 2, dan jawaban $\mathrm{C}$ dengan bobot 1. Jawaban dari angket tersebut dijumlahkan menurut bobot yang telah ditentukan, maka 
Jurnal Penelitian Bahasa dan Sastra Indonesia V1.i1 (57-71)

\begin{tabular}{|c|c|c|}
\hline No & Kode Sampel & Skor \\
\hline 1 & 2 & 3 \\
\hline 1 & 01 & 46 \\
\hline 2 & 02 & 45 \\
\hline 3 & 03 & 44 \\
\hline 4 & 04 & 42 \\
\hline 5 & 05 & 44 \\
\hline 6 & 06 & 43 \\
\hline 7 & 07 & 45 \\
\hline 8 & 08 & 38 \\
\hline 9 & 09 & 43 \\
\hline 10 & 010 & 43 \\
\hline 11 & 011 & 32 \\
\hline 12 & 012 & 44 \\
\hline 13 & 013 & 43 \\
\hline 14 & 014 & 38 \\
\hline 15 & 015 & 30 \\
\hline 16 & 016 & 46 \\
\hline 17 & 017 & 35 \\
\hline 18 & 018 & 28 \\
\hline 19 & 019 & 44 \\
\hline 20 & 020 & 28 \\
\hline 21 & 021 & 40 \\
\hline 22 & 022 & 35 \\
\hline 23 & 023 & 44 \\
\hline 24 & 024 & 30 \\
\hline 25 & 025 & 45 \\
\hline 26 & 026 & 42 \\
\hline 27 & 027 & 45 \\
\hline 28 & 028 & 32 \\
\hline 29 & 029 & 42 \\
\hline 30 & 030 & 40 \\
\hline
\end{tabular}

Skor yang diperoleh antara 28-46, perolehan secara terperinci yaitu (1) skor 46 diperoleh 2 orang sampel (2) skor 45 diperoleh 4 orang sampel (3) skor 44 diperoleh 5 orang sampel (4) skor 43 diperoleh 4 orang sampel (5) skor 42 diperoleh 3 orang sampel (6) skor 40 diperoleh 2 orang sampel (7) skor 38 diperoleh 2 orang sampel (8) skor 35 diperoleh 2 orang sampel (9) skor 32 diperoleh 1 orang sampel (10) skor 30 diperoleh 2 orang sampel (11) skor 28 diperoleh 2 orang sampel. Lebih jelasnya, maka dapat dilihat pada tabel 5 berikut.

\section{Tabel 1. Skor Strategi Membaca Pemahaman}

data, diolah dengan menggunakan rumus persentase. Contoh penggunaan rumus tersebut untuk sampel 01 yang memperoleh skor tertinggi yaitu 46 adalah

$\mathrm{N}(01)=\frac{46}{51} \times 100 \%=90,19$

Angket strategi membaca pemahaman siswa kelas V SDN 04 Paninggahan berjumlah 20 pertanyaan. Jawaban A dengan bobot 3 , jawaban $\mathrm{B}$ dengan bobot 2 , dan jawaban $\mathrm{C}$ dengan bobot 1 . Jika siswa menjawab 20 pertanyaan tersebut 
Jurnal Penelitian Bahasa dan Sastra Indonesia V1.i1 (57-71)

dengan menjawab A, maka jumlah bobotnya 51 .

Tabel 2. Nilai dan Kualifikasi Strategi Membaca Pemahaman

\begin{tabular}{|c|c|c|c|}
\hline No & Sampel & Nilai & Kualifikasi \\
\hline $\mathbf{1}$ & $\mathbf{2}$ & $\mathbf{3}$ & $\mathbf{4}$ \\
\hline 1 & 01 & 90 & baik sekali \\
\hline 2 & 02 & 88 & baik sekali \\
\hline 3 & 03 & 86 & baik sekali \\
\hline 4 & 04 & 82 & baik \\
\hline 5 & 05 & 86 & baik sekali \\
\hline 6 & 06 & 84 & baik \\
\hline 7 & 07 & 88 & baik sekali \\
\hline 8 & 08 & 75 & $\begin{array}{c}\text { lebih dari } \\
\text { cukup }\end{array}$ \\
\hline 9 & 09 & 84 & baik \\
\hline 10 & 010 & 84 & baik \\
\hline 11 & 011 & 63 & cukup \\
\hline 12 & 012 & 86 & baik sekali \\
\hline 13 & 013 & 84 & baik \\
\hline 14 & 014 & 75 & lebih dari \\
& & & cukup \\
\hline 15 & 015 & 59 & cukup \\
\hline 16 & 016 & 90 & baik sekali \\
\hline 17 & 017 & 69 & lebih dari \\
& & & cukup \\
\hline 18 & 018 & 55 & hampir cukup \\
\hline 19 & 019 & 86 & baik sekali \\
\hline 20 & 020 & 55 & hampir cukup \\
\hline 21 & 021 & 78 & baik \\
\hline 22 & 022 & 69 & $\begin{array}{c}\text { lebih dari } \\
\text { cukup }\end{array}$ \\
\hline 23 & 023 & 86 & baik sekali \\
\hline 24 & 024 & 59 & cukup \\
\hline 25 & 025 & 88 & baik sekali \\
\hline
\end{tabular}

\begin{tabular}{|c|c|c|c|}
\hline 26 & 026 & 82 & baik \\
\hline 27 & 027 & 88 & baik sekali \\
\hline 28 & 028 & 63 & cukup \\
\hline 29 & 029 & 82 & baik \\
\hline 30 & 030 & 78 & Baik \\
\hline & Jumlah & 2342 & \\
\hline
\end{tabular}

Nilai yang telah diubah dengan menggunakan rumus persentase, diperoleh nilai strategi membaca pemahaman yang terpilih sebagai sampel penelitian adalah sampel 01 yaitu dengan nilai 90. Nilai tersebut berada pada kualifikasi baik sekali. Sampel yang mendapatkan kualifikasi baik sekali berjumlah 11 orang, kualifikasi baik berjumlah 9 orang, kualifikasi lebih dari cukup berjumlah 4 orang, kualifikasi cukup 4 orang, dan kualifikasi hampir cukup berjumlah 2 orang sampel.

Distribusi frekuensi strategi membaca pemahaman diperoleh rentangan nilai 55-60 dengan persentase 13,3 \%, 61-66 dengan persentase 6,7 \%, 67-72 dengan persentase 6,7 \%, 73-78 dengan persentase 13,3 \%, 79-84 dengan persentase $23,3 \%$ dan rentangan nilai 85-90 dengan persentase 36,7 \%. Frekuensi terbanyak dari nilai strategi membaca pemahaman adalah 11 . Lebih jelasnya dapat dilihat pada tabel berikut.

Tabel 3. Distribusi Frekuensi Strategi Membaca Pemahaman \begin{tabular}{|l|c|c|c|}
\hline No & Nilai & Freku & Persentase \\
\hline
\end{tabular} 


\begin{tabular}{|c|c|c|c|}
\hline & & ensi & \\
\hline $\mathbf{1}$ & $\mathbf{2}$ & $\mathbf{3}$ & $\mathbf{4}$ \\
\hline 1 & $55-60$ & 4 & $13,3 \%$ \\
\hline 2 & $61-66$ & 2 & $6,7 \%$ \\
\hline 3 & $67-72$ & 2 & $6,7 \%$ \\
\hline 4 & $73-78$ & 4 & $13,3 \%$ \\
\hline 5 & $79-84$ & 7 & $23,3 \%$ \\
\hline 6 & $85-90$ & 11 & $36,7 \%$ \\
\hline & Jumlah & 30 & $100 \%$ \\
\hline
\end{tabular}

Histogram di atas diperoleh nilai $54,5,60,5,66,5,72,5,78,5,84,5$. Nilai tersebut didapat dari rentangan nilai 55-60 yaitu 55 dikurang 0,5, maka diperoleh nilai 54,5, 61-66 diperoleh nilai $60,5,67-72$ diperoleh nilai $66,5,73-78$ diperoleh nilai 72,5 , 79-84 diperoleh nilai 78,5, dan rentangan nilai $85-90$ diperoleh nilai 84,5. Jadi, nilai dalam histogram di atas diperoleh dari rentangan nilai dikurang 0,5.

Penentuan rata-rata (M), diperoleh rata-rata strategi membaca pemahaman yaitu 78 (lampiran 13 halaman 89). Menurut penentuan standar deviasi (Sd), diperoleh standar deviasi (Sd) 78,06 (lampiran 13 halaman 89). Artinya, tingkat heterogenesis strategi membaca pemahaman siswa berada pada angka 78,06. Berdasarkan penentuan median, maka diperoleh median 90,14 (lampiran 13 halaman 89). Sedangkan modus dari strategi membaca pemahaman diperoleh nilai 90,76.

\section{Kemampuan Membaca Pemahaman}

Data kemampuan membaca diperoleh melalui tes kemampuan membaca pemahaman. Tes ini berupa tes uraian berbentuk laporan bacaan. Tes tersebut dilakukan dengan menugaskan mahasiswa membuat laporan bacaan dari 5 buah jenis bacaan. Bacaan ditentukan berupa buku teks dan berita yang diambil dari koran. Berdasarkan hasil tes kemampuan membaca pemahaman yang dilaksanakan terhadap 30 sampel penelitian, diperoleh skor sebagai berikut. Skor yang diperoleh antara 76-85, perolehan skor secara terperinci yaitu (1) skor 85 diperoleh 10 orang sampel (2) skor 84 diperoleh 5 orang sampel (3) skor 82 diperoleh 2 orang sampel (4) skor 79 diperoleh 10 orang sampel (5) skor 76 diperoleh 3 orang sampel dapat dilihat pada tabel 4 sebagai berikut.

Tabel 4. Skor Kemampuan Membaca Pemahaman

\begin{tabular}{|c|c|c|c|}
\hline No & $\begin{array}{c}\text { Kode } \\
\text { Samp } \\
\text { el }\end{array}$ & $\begin{array}{c}\text { Jumlah Soal } \\
\text { yang Dijawab } \\
\text { Benar }\end{array}$ & $\begin{array}{c}\text { Sko } \\
\mathbf{r}\end{array}$ \\
\hline $\mathbf{1}$ & $\mathbf{2}$ & $\mathbf{3}$ & $\mathbf{4}$ \\
\hline 1 & 01 & 15 & 85 \\
\hline 2 & 02 & 15 & 85 \\
\hline 3 & 03 & 12 & 79 \\
\hline 4 & 04 & 12 & 79 \\
\hline 5 & 05 & 10 & 76 \\
\hline 6 & 06 & 14 & 84 \\
\hline 7 & 07 & 12 & 79 \\
\hline
\end{tabular}


Jurnal Penelitian Bahasa dan Sastra Indonesia V1.i1 (57-71)

\begin{tabular}{|l|c|c|c|}
\hline 8 & 08 & 10 & 76 \\
\hline 9 & 09 & 15 & 85 \\
\hline 10 & 010 & 12 & 79 \\
\hline 11 & 011 & 11 & 76 \\
\hline 12 & 012 & 12 & 79 \\
\hline 13 & 013 & 14 & 84 \\
\hline 14 & 014 & 15 & 85 \\
\hline 15 & 015 & 14 & 84 \\
\hline 16 & 016 & 13 & 82 \\
\hline 17 & 017 & 15 & 85 \\
\hline 18 & 018 & 12 & 79 \\
\hline 19 & 019 & 12 & 79 \\
\hline 20 & 020 & 15 & 85 \\
\hline 21 & 021 & 12 & 79 \\
\hline 22 & 022 & 14 & 84 \\
\hline 23 & 023 & 12 & 79 \\
\hline 24 & 024 & 14 & 84 \\
\hline 25 & 025 & 15 & 85 \\
\hline 26 & 026 & 15 & 85 \\
\hline 27 & 027 & 12 & 79 \\
\hline 28 & 028 & 15 & 85 \\
\hline 29 & 029 & 13 & 82 \\
\hline 30 & 030 & 15 & 85 \\
\hline
\end{tabular}

Pengolahan skor dengan rumus persentase kemampuan membaca pemahaman secara lengkap dapat dilihat pada tabel 5 dan tabel 6 yaitu,

Tabel 5. Nilai dan Kualifikasi Kemampuan Membaca Pemahaman

\begin{tabular}{|l|c|c|c|}
\hline No & Sampel & Nilai & $\begin{array}{c}\text { Kualifika } \\
\text { si }\end{array}$ \\
\hline $\mathbf{1}$ & $\mathbf{2}$ & $\mathbf{3}$ & $\mathbf{4}$ \\
\hline 1 & 01 & 93 & $\begin{array}{c}\text { baik } \\
\text { sekali }\end{array}$ \\
\hline 2 & 02 & 93 & $\begin{array}{c}\text { baik } \\
\text { sekali }\end{array}$ \\
\hline 3 & 03 & 86 & baik \\
\hline 4 & 04 & 86 & baik \\
\hline 5 & 05 & 83 & baik \\
\hline 6 & 06 & 92 & $\begin{array}{c}\text { baik } \\
\text { sekali }\end{array}$ \\
\hline 7 & 07 & 86 & baik \\
\hline 8 & 08 & 83 & baik \\
\hline 9 & 09 & 93 & $\begin{array}{c}\text { baik } \\
\text { sekali }\end{array}$ \\
\hline 10 & 010 & 86 & baik \\
\hline 11 & 011 & 83 & baik \\
\hline 12 & 012 & 86 & baik \\
\hline 13 & 013 & 92 & $\begin{array}{c}\text { baik } \\
\text { sekali }\end{array}$ \\
\hline 14 & 014 & 93 & $\begin{array}{c}\text { baik } \\
\text { sekali }\end{array}$ \\
\hline 15 & 015 & 92 & $\begin{array}{c}\text { baik } \\
\text { sekali }\end{array}$ \\
\hline 16 & 016 & 90 & $\begin{array}{c}\text { baik } \\
\text { sekali }\end{array}$ \\
\hline 17 & 017 & 93 & $\begin{array}{c}\text { baik } \\
\text { sekali }\end{array}$ \\
\hline 18 & 018 & 86 & baik \\
\hline
\end{tabular}


Jurnal Penelitian Bahasa dan Sastra Indonesia V1.i1 (57-71)

\begin{tabular}{|l|c|c|c|}
\hline 19 & 019 & 86 & baik \\
\hline 20 & 020 & 93 & $\begin{array}{c}\text { baik } \\
\text { sekali }\end{array}$ \\
\hline 21 & 021 & 83 & baik \\
\hline 22 & 022 & 92 & $\begin{array}{c}\text { baik } \\
\text { sekali }\end{array}$ \\
\hline 23 & 023 & 86 & baik \\
\hline 24 & 024 & 92 & $\begin{array}{c}\text { baik } \\
\text { sekali }\end{array}$ \\
\hline 25 & 025 & 93 & $\begin{array}{c}\text { baik } \\
\text { sekali }\end{array}$ \\
\hline 26 & 026 & 93 & $\begin{array}{c}\text { baik } \\
\text { sekali }\end{array}$ \\
\hline 27 & 027 & 86 & baik \\
\hline 28 & 028 & 93 & $\begin{array}{c}\text { baik } \\
\text { sekali }\end{array}$ \\
\hline 29 & 029 & 90 & $\begin{array}{c}\text { baik } \\
\text { sekali }\end{array}$ \\
\hline 30 & 030 & 93 & $\begin{array}{c}\text { baik } \\
\text { sekali }\end{array}$ \\
\hline
\end{tabular}

\begin{tabular}{|l|c|c|c|}
\hline & & & $\%$ \\
\hline 4 & $86-90$ & 1 & $3,3 \%$ \\
\hline 5 & $91-95$ & 16 & 53,3 \\
& & & $100 \%$ \\
\hline & Jumlah & 30 & 10 \\
\hline
\end{tabular}

Distribusi frekuensi kemampuan membaca pemahaman diatas diperoleh rentangan nilai 81-85 dengan persentase $43,3 \%, 86-90$ dengan persentase 3,3\%, dan 91-95 dengan persentase 53,3\%. Frekuensi terbanyak dari nilai kemampuan membaca pemahaman adalah 16 .

Menurut penentuan standar deviasi (Sd), maka diperoleh standar deviasi (Sd) 79,56. Jadi, dapat disimpulkan bahwa standar deviasi kemampuan membaca pemahaman ditemukan 79,56. Artinya, tingkat heterogenesis kemampuan membaca pemahaman siswa berada pada angka 79,56 .

Median adalah suatu nilai yang membatasi separuh frekuensi bagian bawah distribusi dari nilai pengaruh bagian atasnya. Median kemampuan membaca pemahaman ditemukan 81,36. Sedangkan modus merupakan suatu nilai atau suatu golongan gejala yang paling banyak terjadi atau paling besar frekuensinya dan modus kemampuan membaca pemahaman siswa ditemukan yaitu 85 .

\begin{tabular}{|l|c|c|c|}
\hline No & Nilai & Frekuensi & $\begin{array}{c}\text { Perse } \\
\text { ntase }\end{array}$ \\
\hline 1 & $70-75$ & 0 & $0 \%$ \\
\hline 2 & $76-80$ & 0 & $0 \%$ \\
\hline 3 & $81-85$ & 13 & 43,3 \\
\hline
\end{tabular}


Jurnal Penelitian Bahasa dan Sastra Indonesia V1.i1 (57-71)

\begin{tabular}{|c|c|c|c|c|c|c|c|}
\hline \multirow{3}{*}{ 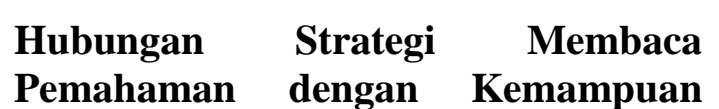 } & & & & & & & \\
\hline & 22 & 022 & 69 & 92 & 4761 & 8464 & 6348 \\
\hline & 23 & 023 & 86 & 86 & 7396 & 7396 & 7396 \\
\hline $\begin{array}{l}\text { Pemahaman dengan Kemampuan } \\
\text { Memahami Teks Bacaan Bahasa }\end{array}$ & 24 & 024 & 59 & 92 & 3481 & 8464 & 5428 \\
\hline Indonesia & 25 & 025 & 88 & 93 & 7744 & 8649 & 8184 \\
\hline membaca & 26 & 026 & 82 & 93 & 6724 & 8649 & 7626 \\
\hline kemampuan & 27 & 027 & 88 & 86 & 7744 & 7396 & 7568 \\
\hline membaca pemahaman, & 28 & 028 & 63 & 93 & 3969 & 8649 & 5859 \\
\hline ditabulasikan & 29 & 029 & 82 & 90 & 6724 & 8100 & 7380 \\
\hline antara keduanya seb & 30 & 030 & 78 & 93 & 6084 & 8649 & 7254 \\
\hline $\begin{array}{l}\text { Tabel 7. Korelasi antara Strategi } \\
\text { Membaca Pemahaman }(\mathbf{X}) \text { dengan }\end{array}$ & & $\begin{array}{c}\text { Juml } \\
\text { ah }\end{array}$ & $\begin{array}{l}23 \\
42\end{array}$ & $\begin{array}{l}26 \\
76\end{array}$ & $\begin{array}{c}1864 \\
42\end{array}$ & $\begin{array}{c}2391 \\
30\end{array}$ & 208728 \\
\hline
\end{tabular}

Kemampuan Memahami Teks Bacaan Bahasa Indonesia (Y)

\begin{tabular}{|c|c|c|c|c|c|c|}
\hline No & $\begin{array}{c}\text { Sam } \\
\text { pel }\end{array}$ & $\mathbf{X}$ & $\mathbf{Y}$ & $\mathbf{X}^{2}$ & $\mathbf{Y}^{2}$ & $\mathbf{X Y}$ \\
\hline $\mathbf{1}$ & $\mathbf{2}$ & $\mathbf{3}$ & $\mathbf{4}$ & $\mathbf{5}$ & $\mathbf{6}$ & $\mathbf{7}$ \\
\hline 1 & 01 & 90 & 93 & 8100 & 8649 & 8370 \\
\hline 2 & 02 & 88 & 93 & 7744 & 8649 & 8184 \\
\hline 3 & 03 & 86 & 86 & 7396 & 7396 & 7396 \\
\hline 4 & 04 & 82 & 86 & 6724 & 7396 & 7052 \\
\hline 5 & 05 & 86 & 83 & 7396 & 6889 & 7138 \\
\hline 6 & 06 & 84 & 92 & 7056 & 8464 & 7728 \\
\hline 7 & 07 & 88 & 86 & 7744 & 7396 & 7568 \\
\hline 8 & 08 & 75 & 83 & 5625 & 6889 & 6225 \\
\hline 9 & 09 & 84 & 93 & 7056 & 8649 & 7812 \\
\hline 10 & 010 & 84 & 86 & 7056 & 7396 & 7224 \\
\hline 11 & 011 & 63 & 83 & 3969 & 6889 & 5229 \\
\hline 12 & 012 & 86 & 86 & 7396 & 7396 & 7396 \\
\hline 13 & 013 & 84 & 92 & 7056 & 8464 & 7728 \\
\hline 14 & 014 & 75 & 93 & 5625 & 8649 & 6975 \\
\hline 15 & 015 & 59 & 92 & 3481 & 8464 & 5428 \\
\hline 16 & 016 & 90 & 90 & 8100 & 8100 & 8100 \\
\hline 17 & 017 & 69 & 93 & 4761 & 8649 & 6417 \\
\hline 18 & 018 & 55 & 86 & 3025 & 7396 & 4730 \\
\hline 19 & 019 & 86 & 86 & 7396 & 7396 & 7396 \\
\hline 20 & 020 & 55 & 93 & 3025 & 8649 & 5115 \\
\hline 21 & 021 & 78 & 83 & 6084 & 6889 & 6474 \\
\hline
\end{tabular}

Berdasarkan data tersebut, dapat dihitung korelasi $\mathrm{X}$ dan $\mathrm{Y}$ yaitu

r $\frac{n \sum x y-\left(\sum x\right)\left(\sum y\right)}{\sqrt{\left\{n \sum x 2-\left(\sum x\right) 2\right\}\left\{n \sum y 2-\left(\sum y\right) 2\right\}}}$

r $=$ $(30 X 208728)-(2342 X 2676)$ $\overline{\sqrt{(30 X 186442)-}(2342) 2 X(30 X 239130)-(2676) 2}$

r $=$ $6267840-6267192$ $\sqrt{(5593260-5484964) X}(7173900-7160976)$ 


$$
\begin{aligned}
& r=\frac{648}{\sqrt{(108296 X} 12924)} \\
& r=0,013725
\end{aligned}
$$

Penghitungan korelasi X (strategi membaca pemahaman) dan korelasi $\mathrm{Y}$ (kemampuan memahami teks bacaan bahasa Indonesia diperoleh nilai 0,013725. Jadi, dapat disimpulkan korelasi $\mathrm{X}$ dan $\mathrm{Y}$ yaitu 0,013725. $\mathrm{X}$ dalam penelitian ini adalah strategi membaca pemahaman. Sedangkan Y adalah kemampuan memahami teks bacaan bahasa Indonesia. Nilai yang didapat dari korelasi $\mathrm{x}$ dan $\mathrm{y}$ yaitu 0,013725 , berarti terdapat hubungan yang positif atau signifikan antara strategi membaca pemahaman dengan kemampuan memahami teks bacaan bahasa Indonesia.

Berdasarkan deskripsi data dan analisis data, diklasifikasikan menjadi enam kategori, yaitu pada rentangan nilai 85-90 diperoleh 11 orang sampel, 79-84 diperoleh 7 orang sampel, 73-78 diperoleh 4 orang sampel, 67-72 diperoleh 2 orang sampel, 61-66 diperoleh 2 orang sampel, dan pada rentangan nilai 55-60 diperoleh 4 orang sampel. Jadi, frekuensi terbanyak strategi membaca pemahaman adalah 11 pada rentangan nilai 85-90. Mean strategi membaca pemahaman yaitu 78 , standar deviasi 78,06, sedangkan median 90,14, dan modus dengan nilai 90,76.
Dilihat dari tes kemampuan membaca pemahaman berada pada kualifikasi "baik sekali" berarti mahasiswa prodi pendidikan bahasa dan sastra Indonesia FKIP UMSB sudah menggunakan dan menerapkan strategi membaca pemahaman dengan baik. Jadi, semakin banyak mahasiswa yang mampu menggunakan dan menerapkan strategi membaca pemahaman semakin baik pula kemampuan dalam memahami teks bacaan.

Strategi membaca pemahaman terdapat hubungan yang sangat erat dengan membaca pemahaman, karena tanpa strategi membaca pemahaman akan kesulitan memahami teks bacaan dengan baik, apabila strategi membaca pemahaman tersebut sudah digunakan dan diterapkan, maka kemampuan dalam memahami teks bacaan akan baik atau akan memperoleh nilai yang tinggi. Dapat disimpulkan bahwa, terdapat hubungan antara strategi membaca pemahaman dengan kemampuan memahami teks bacaan bahasa Indonesia.

Strategi kognitif adalah strategi pembelajaran yang melibatkan manipulasi mental terhadap materi-materi manipulasi atau tugas-tugas dan diharapkan dapat meningkatkan pemahaman, pemerolehan, atau ingatan. Sedangkan strategi metakognitif melibatkan pemikiran atau pengetahuan mengenai proses pembelajaran dan strategi sosial 
atau afektif berhubungan dengan pelajaran menyimak. Strategi yanng lebih berperan kepada kemampuan membaca pemahaman adalah srtategi kognitif.

Berdasarkan penelitian yang telah dilakukan yaitu angket strategi membaca pemahaman dengan nilai rata-rata 78 yang berada pada kualifikasi baik dan tes kemampuan membaca pemahaman diperoleh rata-rata 81 yang berada pada kualifikasi baik sekali. Temuan penelitian yang peneliti jumpai dilapangan berdasarkan persentase skala 10, untuk strategi membaca pemahaman tidak ada yang berada pada kualifikasi kurang, kurang sekali, buruk, dan buruk sekali. Kualifikasi baik sekali berjumlah 17 orang, kualifikasi baik berjumlah 13 orang. Jadi, dapat disimpulkan bahwa tidak ada sampel yang memperoleh nilai dengan kualifikasi sempurna.

\section{Simpulan}

Berdasarkan pendeskripsian, analisis, dan pembahasan data dalam penelitian ini diperoleh kesimpulan. Pertama, strategi membaca pemahaman mahasiswa prodi bahasa dan sastra Indonesia FKIP UMSB terdiri atas 5 kategori yaitu baik sekali, baik, lebih dari cukup, cukup, dan hampir cukup. Dilihat dari tes kemampuan membaca pemahaman berada pada kualifikasi "baik sekali" berarti sudah menggunakan dan menerapkan strategi membaca pemahaman dengan baik. Jadi, semakin banyak yang mampu menggunakan dan menerapkan strategi membaca pemahaman semakin baik pula kemampuan dalam memahami teks bacaan.

Terdapat hubungan antara strategi membaca pemahaman dan kemampuan memahami teks bacaan bahasa Indonesia pada mahasiswa semester $\mathrm{V}$ prodi bahasa dan sastra Indonesia FKIP UMSB. Jika strategi membaca pemahaman tinggi, kemampuan membaca pemahaman juga tinggi, sebaliknya apabila strategi membaca pemahaman rendah kemampuan membaca pemahaman juga akan rendah.

Agar tingkat pemahaman terhadap isi bacaan lebih baik, perlu diterapkan strategi membaca yang tepat untuk memahami teks bacaan. Di samping itu, perlu dekembangakan dan ditingkatkan kemampuan membaca pemahaman agar adanya pertambahan dan perkembangan wawasan lebih mendalam.

\section{Daftar Rujukan}

Abdullah, Aliah. 1980. Pengajaran

Membaca Kritis. Jakarta: P3G,

Depdikbud.

Abdurahman dan Elya Ratna. 2003. "Evaluasi Pembelajaran Bahasa dan Sastra Indonesia". (Buku Ajar). Padang: FBSS UNP.

Agustina. 2008. Pembelajaran Keterampilan Membaca. Padang: 
Jurusan Bahasa dan Sastra Indonesia dan Daerah UNP.

Ali, Lukman. 1995. Kamus Besar Bahasa Indonesia Edisi 2. Jakarta: Balai Pustaka.

Arikunto. S. 2006. Prosedur Penelitian. Jakarta: PT. Rineka Cipta.

Depertemen Pendidikan Dan kebudayaan. 2000.

Penyempurnaan/Penyesuaian Kurikulum $1994 \quad$ (Suplemen $G B P B)$. Jakarta: Depdikbud.

Ermanto. 2008. Keterampilan Membaca Cerdas. Padang: UNP Press.

Harjasujana, A. S. 1988. Materi Pokok Membaca. Jakarta: Karunika, Universitas Terbuka.

Marhiyanto, Bambang. 2007. Pintar Bahasa Indonesia. Surabaya: Gitamedia Press.

Nazir. M. 2005. Metode Penelitian. Jakarta: Ghalia Indonesia.

Nurhadi. 1987. Membaca Cepat dan Efektif. Malang: Sinar Baru Algesindo.

Sudjana. 2005. Metode Statistika. Bandung: PT. Tarsito.

Sugiyono. 2009. Metode penelitian Kuantitatif, Kualitatif dan $R \& D$. Bandung: Alfabeta.

Supriyadi, dkk. 1995. Pendidikan Bahasa Indonesia 2. jakarta: Universitas Terbuka.

Tampubolon. 1993. Mengembangkan Minat dan Kebiasaan Membaca Pada Anak. Bandung: Angkasa.
Tarigan. H. G. 1991. Strategi pengajaran dan Pembelajaran Bahasa. Bandung: Angkasa.

Tarigan, H. G, dkk. 1990. Membaca dalam Kehidupan. Bandung: Angkasa.

Tarigan. H. G. 1979. Membaca Sebagai Suatu Keterampilan Berbahasa. Bandung: Angkasa. 